\title{
Nåleskovens velsignelser og forbandelser - Flora og Fauna 110 (3) 2004, 58-137
}

Anmeldt af lektor Kristian Dalsgaard, Geologisk Institut, Aarhus Universitet

Naturhistorisk Forening For Jylland afholdt sidste forår en konference med overstående titel, og de 14 indlæg er prisværdigt udgivet i ovenstående hæfte. Baggrunden for konferencen er den dominerende rolle, som nåleskoven, specielt rødgranen, har fået i skovbilledet.

Peter Friis Møller indleder med at behandle nåletræernes historie i Danmark både de naturligt indvandrede og den forstlige nåleskov og diskuterer mulige årsager til, at nåletræerne med få undtagelser ikke er indvandret i Holocæn i modsætning til tidligere mellemistider.

\section{Potentiel afløser til rødgranen}

Statsskovbrugets indstilling til nåletræerne rolle, som har undergået en kraftig ændring de sidste 20 år, dækkes af Niels Juhl Bundgaard, som har en forståelig svaghed for store gamle nåletræer. Han fremhæver bl.a. douglasgranen med dens gode egenskaber, som en potentiel afløser til rødgranen og er inde på, at mange af nåletræerne er gode til selvforyngelse, hvilket passer godt til den

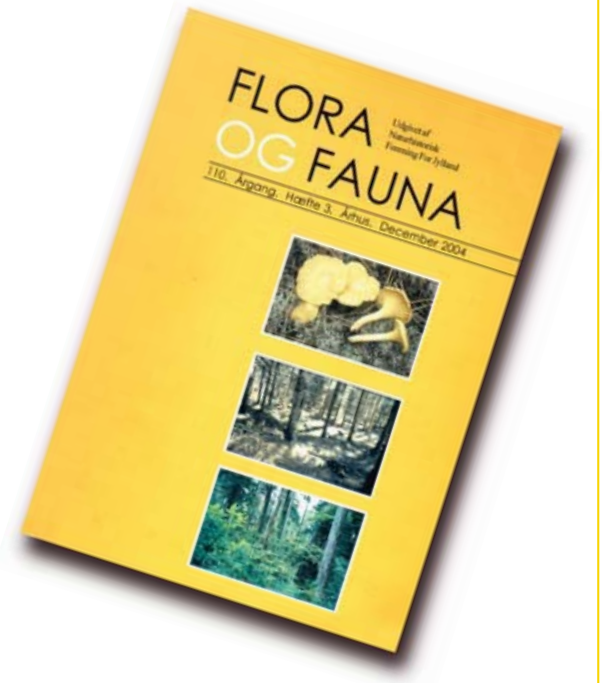

naturnære skovdrift, man er ved at slå ind på.

Bent Jørgensen fra Skov og Naturstyrelsen behandler initiativer omkring naturgenopretning i nåleskovsarealer, hvor man tilstræber at genskabe de oprindelige naturtyper.

\section{Lav biodiversitet}

En række indlæg af specialister dækker den lave biodiversitet, der knytter sig til nåleskovene. De omfatter svampe, mosser, karsporeplanter, pattedyr, fuglebiller, biller og sommerfugle. Et interessant aspekt er, at nåletræerne har opnået accept som en del af den danske natur, og at der er ønske om urørte nåletræsområder, som får lov til at blive gamle, så man kan følge udviklingen $\mathrm{i}$ biodiversiteten.

Håb om mere varieret natur Peder Agger, som har fulgt udviklingen siden 1970erne, opsummerer og konkluderer, at ændringerne til naturens fordel har overhalet de ønsker, der har været rejst. Det kunne være nævnt, at det nok skyldes faldende priser for skovbrugets produkter. Skov og Naturstyrelsen lægger således meget vægt på "at sælge" natur og det private skovbrug på jagt. Begge dele fremmer jo en mere varieret natur. Alt $i$ alt giver hæftet en god oversigt over emnets øjeblikkelige status og giver håb om mere varieret natur for vore efterkommere.

Flora og Fauna, 110. årgang, hoefte 3. Arhus, december 2004. Bidrag fra forskellige forfattere i forbindelse med konferencen afholdt 6. marts 2004: Nåleskovens velsignelser og forbandelser. Hoeftet koster $50 \mathrm{kr}$. og kan bestilles hos Eigil Holm på e-mail: eigil.holm@pc.dk eller 86129777 (Naturhistorisk Museum)

\section{Kort nyt}

Verdens største pseudo-kalkstenshule På øen Cheju i Korea er verdens hidtil største pseudo-kalkstenshule fundet. Pseudokalksten hentyder til, at der er tale om en sekundær kalkstenshule omdannet fra en lavagrotte af vand.

Dr. Son In-seok, geolog og underviser på Daejeong High School, udtaler: "Hulen er mindst 2,5 km lang og rig på formationer af calcitstalaktitter og stalagmitter. Så vidt vi ved, er der ingen pseodu-kalkstenshule som denne i verden. Indtil nu har Hwaggum-hulen - lokaliseret på samme ø - været den største af sin slags med sine $120 \mathrm{~m}$.

Ifølge Son strækker hulen sig langs Woljong-ni og Kimnyong-ni I Kujwa-up, den nordøstlige den af Koreas største ø. Dimensionerne ligger mellem 3 til 10 meter i bredde og 1 til 25 meter i højde.

Nogle ingeniører fandt en åbning til hulen, mens de rejste en elmast, og rapporterede det til myndighederne. Der er nu planer om at registrere hulen som en UNESCO verdensarvs-lokalitet. Øen har allerede verdens største lavahule, den 7,5 km lange Manjang Hule.

Indtil videre er pseudo-kalkstenshulen blevet navngivet "Yongchon Cave", hvilket betyder Dragens kilde - taget efter en 12 meter dyb kilde fundet $i$ den nordlige del af hulen.

http://times.hankooki.com/PBSJ 